\title{
THE ROLE OF OPENING CLAUSES IN HARMONIZATION OF EU LAW: EXAMPLE OF THE EU'S GENERAL DATA PROTECTION REGULATION (GDPR)
}

\author{
Emilia Mišćenić, PhD, Associate Professor \\ University of Rijeka, Faculty of Law \\ Hahlic 6, 51000 Rijeka, Croatia \\ emiscenic@pravri.hr
}

\author{
Anna-Lena Hoffmann, PhD Candidate \\ University of Rijeka, Faculty of Law \\ Stuttgart, Germany \\ anna.lena.hoffmann@icloud.com
}

\begin{abstract}
As the main tool for the achievement of the proper functioning of the internal market, the Union is focused on the process of harmonization. The role of harmonization in the EU's internal market is to remove barriers to trade and to facilitate free movement of goods, persons, services, and capital (as well as payment). This can be achieved in many ways, including through the adoption of harmonization, i.e., approximation measures, such as directives and regulations. The established CJEU case law confirms that the aim of harmonization measures is to 'reduce disparities between legal systems.' This aim's realization very often depends upon the form of the chosen harmonization measure and the level of harmonization the measure is based on (e.g., minimum, maximum, full (targeted) harmonization). However, today, we are faced with changes in the regulatory approach of the EU legislator and these changes are greatly affecting the process of harmonization. Due to the increased level of harmonization, EU directives are starting to appear and function more like EU regulations, and vice versa. Because of numerous optional clauses, clauses of minimal harmonization, and the so-called 'opening clauses', EU regulations are not reducing but enabling 'disparities between legal systems.' As an example, authors are analyzing the EU's General Data Protection Regulation (GDPR) containing more than 69 opening clauses, which play an important role in the process of harmonization and present an instrument of interplay between EU law and Member States' laws.
\end{abstract}


Therefore, it remains to be answered within the lines of this paper whether the role of opening clauses is in compliance with the aim of harmonization in the EU law.

Keywords: General Data Protection Regulation; opening clauses; harmonization; approximation; level of harmonization; internal market; full effect; EU law

\section{INTRODUCTION}

There are numerous definitions of the concept of harmonization. However, generally speaking, it describes a process within which different parts of a whole are being aligned with each other. ${ }^{1}$ In the context of European Union's (EU) legal framework, it means that the differences between legal orders of Member States are alleviated or removed through approximation of laws. The 'approximation of laws,' as regulated in the Treaty on the Functioning of the European Union (TFEU), ${ }^{2}$ follows the objective of establishment and functioning of the internal market. Art. 26(2) TFEU defines the internal market as "an area without internal frontiers in which the free movement of goods, persons, services and capital is ensured in accordance with the provisions of the Treaties." Therefore, harmonization, i.e., approximation of laws plays an important role in the achievement of one of the Union's main goals, namely, the internal market. The approximation of laws and removal of differences between Member States' legal solutions leads to an increased level of legal certainty for those participating on the internal market. ${ }^{3}$ This results in an increase of business transactions and facilitates free movement of goods and services. ${ }^{4}$ As emphasized by Advocate General Stix-Hackl in her Opinion in the case Parliament $v$ Council, the aim of the approximation of laws (within the meaning of ex Art. 95 EC; now Art. 114 TFEU) is to "reduce disparities between legal systems." 5

1 An in-depth analysis was given by Lohse, E. J., The Meaning of Harmonisation in the Context of European Community Law - a Process in Need of Definition, in: Andenas, M. T.; Baasch Andersen, C., (eds.), Theory and Practice of Harmonisation, Edward Elgar, Cheltenham, 2012, pp. 282 et seq. See also Klamert, M., What We Talk About When We Talk About Harmonisation, Cambridge Yearbook of European Legal Studies, no. 17, 2015, pp. 360 et seq.

2 Consolidated version of the Treaty on the Functioning of the European Union [2016] OJ C 202/1, Part III, Title VII, Chapter 3

3 Mišćenić, E., Legal Risks in Development of EU Consumer Protection Law, in: Mišćenić, E.; Raccah A. (eds.), Legal Risks in EU Law, Interdisciplinary Studies on Legal Risk Management and Better Regulation in Europe, Springer International, Cham, 2016, p. 139

4 Halson, R.; Campbell, D., Harmonisation and its discontents: A transaction costs critique of a European contract law, in: Devenney, J.; Kenny, M. (eds.), The Transformation of European Private Law: Harmonisation, Consolidation, Codification or Chaos? Cambridge University Press, Cambridge, 2013, pp. 101 et seq.

5 Opinion of AG Stix-Hackl of 12 July 2005, Case C-436/03, Parliament v Council [2006] ECR I-03733, para. 59 
However, the concepts surrounding the process of harmonization at the EU level are rather blurry and, despite terminological and substantial differences, the Treaties use the terms 'approximation' and 'harmonization' synonymously. ${ }^{6}$ Moreover, in the context of the harmonization process, the completion of the internal market in the European Economic Area (EEA) is not to be equated with the achievement of perfectly unified laws within the Member States, i.e., unification. ${ }^{7}$ Such an option is precluded by the principle of conferral regulated in Art. 5(2) of the Treaty on European Union (TEU). ${ }^{8}$ By setting the limits to the competences of the Union, this provision also sets the limits to legislative powers of the EU legislator. ${ }^{9}$ Furthermore, according to the principle of subsidiarity, the Union can use its legislative powers and act "only if and in so far as the objectives of the proposed action cannot be sufficiently achieved by the Member States, either at central level or at regional and local level, but can rather, by reason of the scale or effects of the proposed action, be better achieved at Union level" (Art. 5(3) TEU). As confirmed by the CJEU in the famous Tobacco Advertising case, ${ }^{10}$ the adoption of harmonization measures cannot be justified by mere existence of differences between national rules of Member States' laws and the abstract risk of the proper functioning of the internal market. ${ }^{11}$

It is not uncommon for measures of EU secondary law to enable a wide level of discretion to Member States when harmonizing their national laws. This can be expressed, for example, in the form of clauses containing various options for Member States (e.g., optional clauses) or clauses departing from the minimal standard of protection that can be increased at the national level (e.g., minimum harmonization clauses). In doing so, the Union is adopting legislative measures aiming at the harmonization, i.e., approximation of laws, but at the same time allowing the creation of further differences between the laws of Member States. ${ }^{12}$ As one recent example of a harmonization measure clearly undermining the aim, i.e., the main goal of harmonization is the famous General Data Protection Regula-

6 Lohse, op. cit., note 1, pp. 282 et seq.

7 On differences between these two notions see Gebauer, M, Unification and Harmonization of Laws, in: Max Planck Encyclopedias of International Law [MPIL], 2009; Lohse, op. cit., note 1, pp. 282 et seq.

8 Consolidated version of the Treaty on European Union [2016] OJ C 202/13

9 Craig, P.; de Burca, G., EU Law: Text, Cases, and Materials, Oxford University Press, 6th ed., 2015, pp. 73 et seq.

10 ECJ, Case C-376/98, Germany v Parliament and Council [2000] ECR I-08419

11 In this case, the ECJ ruled that the Tobacco Advertising Directive cannot be adopted on the legal ground of ex Art. $95 \mathrm{EC}$ since it does not "genuinely" contribute to the proper functioning of the internal market. For an in-depth analysis see Annegret, E., The Choice of Legal Basis for Acts of the European Union: Competence Overlaps, Institutional Preferences, and Legal Basis Litigation, Springer International Publishing, Cham, 2018, pp. 51 et seq.

12 Mišćenić, op. cit., note 3, p. 150 
tion (GDPR), ${ }^{13}$ containing more than 69 of the so-called "opening clauses." ${ }^{14}$ To this purpose, the authors initially analyzed regulations and directives as the main tools of EU harmonization, then focused on the concept of opening clauses by using GDPR examples and, finally, reflected on the role of opening clauses in the harmonization of EU law.

\section{REGULATIONS AND DIRECTIVES AS MEANS OF HARMONIZATION OF EU LAW}

Among the sources of EU secondary law (Art. 288 TFEU), ${ }^{15}$ the EU regulations and directives are the most frequently used legal instruments of harmonization within the EU legal framework. Pursuant to Art. 288(2) TFEU, regulations have general application, are binding in their entirety and directly applicable in all Member States. ${ }^{16}$ It is due to these characteristics that legal scholars place them at the same level of legal hierarchy as national statutory acts of Member States. ${ }^{17}$ Since an EU regulation has a general and direct application, it is not necessary to implement it at the level of Member States. ${ }^{18}$ However, in some cases, implementation measures are required by EU regulations themselves in order to ensure uniform application across the Union. ${ }^{19}$ General and direct applicability of EU regulations can, therefore, result in the exclusion of possibility to apply Member States' national law that is in direct collision with the EU regulation. ${ }^{20}$ Provided that the provisions of the regulation are clearly formulated, this secondary law

13 Regulation (EU) 2016/679 on the protection of natural persons with regard to the processing of personal data and on the free movement of such data, and repealing Directive 95/46/EC (General Data Protection Regulation) [2016] OJ L 119/1 (GDPR)

14 Obwexer, W., Harmonisierung und Optionalität - stehen Öffnungsklauseln der Verwirklichung des Binnenmarkts entgegen?, in: König, D.; Uwer, D. (Eds.), Grenzen Europäischer Normgebung, 1. ed., Bucerius Law School Press, Hamburg, 2015, pp. 54 et seq.; Laue, P., Öffnungsklauseln in der DS-GVO Öffnung wohin? Geltungsbereich einzelstaatlicher (Sonder-)Regelungen, ZD, C.H. Beck, Munich, 2016, pp. 643 et seq.

15 Craig; de Burca, op. cit., note 9, pp. 106 et seq.

16 ECJ, Case C-101/76 Koninklijke Scholten Honig v Council and Commission [1977] ECR 797, para. 21

17 Lorenzmeier, S., Europarecht - schnell erfasst, $5^{\text {th }}$ ed., Springer, Berlin, Heidelberg, 2017, p. 145

18 ECJ, Case C-34/73 Fratelli Variola SpA. v Amministrazione delle finanze dello Stato [1973] ECR 98, para. 10

19 E.g. Regulation (EU) No 524/2013 on online dispute resolution for consumer disputes and amending Regulation (EC) No 2006/2004 and Directive 2009/22/EC [2013] OJ L 165/1; Commission Implementing Regulation (EU) 2015/1051 on the modalities for the exercise of the functions of the online dispute resolution platform, on the modalities of the electronic complaint form, and on the modalities of the cooperation between contact points provided for in Regulation (EU) No 524/2013 of the European Parliament and of the Council on online dispute resolution for consumer disputes [2015] OJ L $171 / 1$

20 Craig; de Burca, op. cit., note 9, p. 105; Lorenzmeier, op. cit., note 17, p. 147 
instrument can offer a strong harmonization effect. As stated by the CJEU in the case Politi v Ministero delle finanze, ${ }^{21}$ "regulations have direct effect and are as such, capable of creating individual rights which national courts must protect." 22 However, this is not always the case since, on many occasions, the provisions of secondary law harmonizing measures, including both regulations and directives, are in the need of further interpretation. ${ }^{23}$ When it comes to EU directives, harmonization seems to be of less intensity due to the legal nature and functioning of this harmonization measure. According to its definition from Art. 288(3) TFEU, an EU directive is binding upon Member States with regard to the result to be achieved and leaves a discretion to Member States with respect to the choice of form and methods. Since EU directive must be implemented in every Member State, differences can occur during the approximation process, which undermines the aim of harmonization at EU level. ${ }^{24}$

Although the intensity of harmonization can be higher or lower depending upon the chosen harmonization measure, there is another aspect that can affect the aim of harmonization. This is the level of harmonization that the chosen harmonization measure is based on. The effectiveness of the harmonization process is highly dependent upon the level or grade of harmonization of certain measure. For example, an EU directive can lead to a more intensive harmonization if it has a fully harmonizing effect, ${ }^{25}$ while an EU regulation can result in a weak degree of harmonization, if it contains many options or derogation rules. The so-called maximum harmonization approach, also known as 'full,' 'full targeted,' or in some cases called 'complete' harmonization, belongs to the strongest level of harmonization. ${ }^{26} \mathrm{Al}$ though these are substantially and terminologically differentiating notions, both the legal scholars and practice are using these terms to describe the high intensity or level of harmonization of the measure. The maximum or full (targeted) harmonization prevents the creation of further differences between the laws of Member States by preventing them from maintaining or introducing provisions into national laws that diverge from those laid down in the harmonization measure. ${ }^{27}$ Its use has in-

$21 \quad$ ECJ, Case C-43/71 Politi v Ministero delle finanze [1971] ECR 1039

22 ECJ, Case C-43/71 Politi v Ministero delle finanze [1971] ECR 1039, para. 9

23 Mišćenić, E., Uniform Interpretation of Article 4(2) of UCT Directive in the Context of Consumer Credit Agreements: Is it possible? Revue du droit de l'Union européenne, no. 3, pp. 127 et seq.

24 Mišćenić, op. cit., note 3, p. 153

25 Müller-Graff, P.-C., EU Directives as a Means of Private Law Unification, Towards a European Civil Code, in: Hartkamp, A. et al. (eds.), 4 ${ }^{\text {th }}$ ed., Wolters Kluwer, Alphen aan der Rijen, 2011, p. 149

26 Schröder, M., EUVIAEUV, in: Streinz (eds.), $3^{\text {rd }}$ ed., C.H. Beck, Munich, 2018, Art. 114 AEUV, para. 46

27 See Mak, V., Full Harmonization in European Private Law: A Two-Track Concept, European Review of Private Law, no. 20, 2012, pp. 213 et seq.; Mišćenić, op. cit., note 3, p. 147 
creased in EU directives from 2000 onwards, as a reaction to the shortcomings of the minimum harmonization approach. ${ }^{28}$ The latter has enabled the Member States to introduce or maintain more stringent and protective national rules, thus creating further differences between Member States laws. ${ }^{29}$ From the objectives and the wording of the harmonization measure, it can usually be easy to determine whether the chosen source of EU secondary law is pursuing a minimum, maximum, or full harmonization approach. ${ }^{30}$ For example, under the title 'Level of harmonisation,' the wording of Art. 4 of Consumer Rights Directive ${ }^{31}$ clearly demonstrates that this harmonization measure follows the full targeted harmonization approach. ${ }^{32}$ This can be further supported by several recitals of its preamble explaining the objectives of this EU directive. ${ }^{33}$ It is also possible for a harmonization measure, either EU directive or regulation, to have a full harmonization effect with respect to certain provisions, but not all of them. ${ }^{34}$ An example of such an EU harmonization measure is the Mortgage Credit Directive. ${ }^{35}$ This EU directive, which is based on the minimum harmonization level, ${ }^{36}$ fully harmonizes the rules on the annual

28 Critically on the issue Weatheril, S., Law and Values in the European Union, Oxford University Press, 2016, pp. 269 et seq. See Proposal for a Regulation of the European Parliament and of the Council on a Common European Sales Law, COM/2011/0635 final - 2011/0284 (COD): "The Union initially started to regulate in the field of contract law by means of minimum harmonisation Directives ... The minimum harmonisation approach meant that Member States had the possibility to maintain or introduce stricter mandatory requirements than those provided for in the acquis. In practice, this approach has led to divergent solutions in the Member States even in areas which were harmonised at Union level. In contrast, the recently adopted Consumer Rights Directive fully harmonises the areas of ..."

29 Weatheril, S., Maximum versus Minimum Harmonization: Choosing between Unity and Diversity in the Search for the Soul of the Internal Market, in: Shuibhne N. N.; Gormley L. W. (eds.), From Single Market to Economic Union: Essays in Memory of John A. Usher, Oxford University Press, Oxford, 2012, pp. 175 et seq.

30 With the exception of some EU directives such as Product Liability Directive, qualified by the CJEU in case C-183/00, Gonzales Sanchez, EU:C:2002:255, paras. 25 and 28 as full harmonization directive. See Schröder, op. cit. note. 26, para. 46

31 Directive 2011/83/EU on consumer rights, amending Council Directive 93/13/EEC and Directive 1999/44/EC of the European Parliament and of the Council and repealing Council Directive 85/577/ EEC and Directive 97/7/EC of the European Parliament and of the Council [2011] OJ L 304/64 (Consumer Rights Directive)

32 Consumer Rights Directive, Art. 4: "Member States shall not maintain or introduce, in their national law, provisions diverging from those laid down in this Directive, including more or less stringent provisions to ensure a different level of consumer protection, unless otherwise provided for in this Directive."

33 Consumer Rights Directive, preamble, recitals 5 and 7

34 ECJ, Case C-11/92 The Queen $v$ Secretary of State for Health, ex parte Gallaher and Others [1993] ECR I-03545. See Schröder, op. cit., note. 26, para. 46

35 Directive 2014/17/EU on credit agreements for consumers relating to residential immovable property and amending Directives 2008/48/EC and 2013/36/EU and Regulation (EU) No 1093/2010 [2014] OJ L 60/34 (Mortgage Credit Directive)

36 Mortgage Credit Directive, Art. 2 
percentage rate and the pre-contractual information duty (European Standardized Information Sheet, ESIS information sheet). ${ }^{37}$

Another interesting example in the context of EU harmonization measures is certainly the famous GDPR, where there is an ongoing debate on the harmonizing effect of its provisions. Although the GDPR is much more detailed than its predecessor, the EU Data Protection Directive (DPD),${ }^{38}$ there is uncertainty about the harmonizing intensity of its provisions. ${ }^{39}$ The GDPR deliberately does not regulate specific details and, instead, establishes the rules and basic principles that are intended to ensure a 'uniform' level of data protection across different technologies and during various development stages. ${ }^{40}$ However, it allows Member States to maintain or introduce 'sector-specific' laws and exceptions for the public sector and small and medium-sized enterprises. ${ }^{41}$ Despite the initial idea of achieving a high level of harmonization by introducing uniform rules for all Member States by means of an EU regulation, ${ }^{42}$ the GDPR allows diverging solutions in many of its aspects. In doing so, it creates further inconsistencies between the legal solutions at the level of Member States, thereby contributing to legal uncertainty for those affected by its rules. More than 69 opening clauses, some of which will be presented and analyzed in this paper, open up space for different legal solutions, interpretations, and, eventually, application in practice. Opening clauses also af-

37 See Mišćenić, E., Mortgage Credit Directive (MCD): Are Consumers Finally Getting the Protection They Deserve? in: Slakoper, Z. (ed.), Liber amicorum in honorem Vilim Gorenc, Faculty of Law, University of Rijeka, 2016, p. 221

38 Directive 95/46/EC of the European Parliament and of the Council of 24 October 1995 on the protection of individuals with regard to the processing of personal data and on the free movement of such data [1995] OJ L 281

39 See discussion in German legal doctrine on full harmonization: pro Ehmann, E.; Selmayr, M. (eds.), Datenschutz-Grundverordnung: DS-GVO, $2^{\text {nd }}$ ed., C.H. Beck, Munich, 2018, para. 88; Pötters, S. Datenschutz-Grundverordnung: DS-GVO, in: Gola, P (eds.), $2^{\text {nd }}$ ed., C.H. Beck, Munich, 2018, Art. 1, para. 24; contra Kühling, J.; Martini, M., Die Datenschutz-Grundverordnung: Revolution oder Evolution im europäischen und deutschen Datenschutzrecht?, EuZW, C.H. Beck, Munich, 2016, p. 454; Laue, op. cit., note 14, p. 463; Hofmann, J.; Johannes, P., DS-GVO: Anleitung zur autonomen Auslegung des Personenbezugs, ZD, C.H.Beck, Munich, 2017, p. 221; Roßnagel, A., Umsetzung der Unionsregelungen zum Datenschutz - Erste Erfahrungen mit der Datenschutz-Grundverordnung aus rechtswissenschaftlicher Sicht, DuD, Springer Gabler, Wiesbaden, 2018, p. 741

40 Ehmann; Selmayr, M., op. cit., note 39, para. 82

${ }_{41}$ GDPR, preamble, recitals 9 and 10. As an example see Draft Law of the Federal Government (germ. Bundesregierung) to adapt the German Data Protection Law to GDPR (germ. Entwurf eines Gesetzes zur Anpassung des Datenschutzrechts an die Verordnung (EU) 2016/679 und zur Umsetzung der Richtlinie (EU) 2016/680, Datenschutz-Anpassungs-und -Umsetzungsgesetz EU - DSAnpUG-EU), BT-Drs. $18 / 11325,24.2 .2017$, p. 73

42 ECJ, Case C-819/79 Germany v Commission [1981] ECR 21, para. 10: "In fact, the provisions of Community regulations must be uniformly applied in all the Member States and have, so far as possible, the same effect throughout the territory of the Community." 
fect the legal nature and level of harmonization of the GDPR, which is very often described by legal scholars as a directive wearing the suit of a regulation. ${ }^{43}$

\section{DEFINITION AND CONCEPT OF OPENING CLAUSES}

Despite the use of opening clauses in harmonization measures of EU secondary law, there is no uniform definition of opening clauses. According to Müller, the origin of the notion describing such clauses as 'opening' ones comes from the legal doctrine. ${ }^{44}$ The term 'opening' is used to accentuate the imperfection of legal clauses that are in need of further concretization..$^{45}$ Opening clauses contained in secondary law harmonization measures are, in principle, allowing or prescribing mandatory derogations for the Member States, thus leading to intensive interaction but also competition between EU law and Member State laws. ${ }^{46}$ As properly explained by Müller, opening clauses in EU harmonization measures allow the introduction or maintenance of "corresponding, deviating or supplementary" provisions at the national level of Member States. ${ }^{47}$ For example, an opening clause can stipulate which provisions and under what conditions are applicable at the national level of Member States within the limits of the scope of application of the relevant EU secondary law act. ${ }^{48}$

The use of opening clauses in an EU harmonization measure affects significantly the level of harmonization of the respective measure. Depending on their content, opening clauses can have a stronger or weaker impact on the harmonization of national laws of Member States, thus strengthening or weakening the very legal nature of the chosen EU harmonization measure. A striking example of an EU regulation, whose legal nature and level of harmonization has been affected by more than 69 opening clauses, is the GDPR. This important issue is vividly discussed both by the legal scholars and practitioners. The result of it is not only the interpretation of the meaning and possible effects of every single opening clause, but also a variety of categories in which these opening clauses can be divided, such

43 Kühling; Martini, op. cit., note 39, p. 448; Bozkurt, Ö., EU-DSGVO und Compliance. Rechtliche und wirtschaftliche Herausforderungen, Igel Verlag RWS, Hamburg, 2018, p. 37

44 Müller, M. Die Öffnungsklauseln der Datenschutzgrundverordnung - Ein Beitrag zur Europäischen Handlungsformenlehre, Wissenschaftliche Schriften der WWU, Münster, 2018, p. 51

45 Ibid., p. 52

46 Kühling, J. et al., Die Datenschutz-Grundverordnung und das nationale Recht-Erste Überlegungen zum innerstaatlichen Regelungsbedarf, Monsenstein und Vannerdat, Münster, 2016, p. 9

47 Müller, op. cit., note 44, p. 54

48 Ibid., p. 59; Schwartmann, R. et al., DS-GVO/BDSG, Datenschutz-Grundverordnung Bundesdatenschutzgesetz, C.F. Müller, Heidelberg, 2018, Art. 6 DSGVO, para. 158 
as obligatory i.e. mandatory and facultative, general and specific, genuine and non-genuine, and other sorts of opening clauses under the GDPR. ${ }^{49}$

\section{OPENING CLAUSES UNDER THE GENERAL DATA PROTECTION REGULATION (GDPR)}

The legal scholars and practitioners are trying to find a way to systemize and divide numerous GDPR opening clauses into certain categories, depending upon their content, legal nature, and level of harmonization. ${ }^{50}$ The most accepted distinction in legal doctrine is the one between facultative and mandatory opening clauses. ${ }^{51}$ Depending upon their legal nature, many opening clauses in the GDPR can be classified as obligatory, i.e. 'mandatory' or 'facultative' clauses. For example, the content of the clause contained in Art. 54 GDPR, pursuant to which each Member State must introduce the necessary rules to establish a supervisory authority, is described as obligatory by legal doctrine. ${ }^{52}$ Therefore, the opening clauses of mandatory nature can regulate at the national level in the form of setting up authorities, assigning responsibilities, or specifying cooperation. On the other hand, the content of the opening clauses of facultative nature does not necessarily need to be observed by Member States, and, in many cases, Member States can depart from the prescribed content..$^{53}$ E.g., the third sentence of Art. 8(1) GDPR enables Member States to depart from the prescribed age limit of 16 years for a child's consent in relation to information society services by reducing it to a lower age, provided that such lower age is not below 13 years. ${ }^{54}$

Legal scholars offer another differentiation of opening clauses depending upon the subject matter of respective clauses as to 'general' and 'specific' opening clauses

49 On various opening clauses see Voigt, P.; von dem Bussche, A., The EU General Data Protection Regulation (GDPR): A Practical Guide, Springer, Cham, 2017, pp. 219 et seq. On different types of opening clauses see also Chakarova, K. Y., General Data Protection Regulation: Challenges Posed by the Opening Clauses and Conflict of Laws Issues, Stanford-Vienna European Union Law Working Paper no. 41, 2019, pp. 11 et seq.

50 See Voigt; von dem Bussche, op. cit., note 49, pp. 219 et seq.; Voigt, P.; von dem Bussche, A., EU-Datenschutz-Grundverordnung (DSGVO), Springer, Berlin, Heidelberg, 2018, pp. 289 et seq.; Chakarova, op. cit., note 49, pp. 11 et seq.; Müller, op. cit., note 44, pp. 98 et seq.; Bozkurt, op. cit., note 43, p. 17; Feiler, L.; Forgó N., EU-DSGVO: EU-Datenschutz-Grundverordnung, Verlag Österreich, Wien, 2016

51 See Kühling et al., op. cit., note 46, p. 9; Bozkurt, op. cit., note 43, p. 18; Schwartmann et al., op. cit., note 48 , para. 165

52 Müller, op. cit., note 44, p. 176. According to Art. 54 GDPR each Member State is required to provide by law establishment of each supervisory authority, qualifications and eligibility conditions required for members of these authorities, rules and procedures for their appointment etc.

53 Schwartmann et al., op. cit., note 48, para. 165

54 Bozkurt, op. cit., note 43, p. 18 
under the GDPR. ${ }^{55}$ If a certain clause offers several options to Member States without limitation in relation to its subject matter, according to this systematization, the clause will be characterized as general. In cases where the opening clause is affecting only a specific subject matter allowing the introduction of minor discrepancies, it will be characterized as specific. ${ }^{56}$ For example, it is considered that Art. 23 GDPR, dealing with the restriction of rights of data subjects, ${ }^{57}$ or Art. $85 \mathrm{GDPR}$, on the relation of GDPR requirements with (fundamental) rights to freedom of expression and information, belong to general opening clauses. ${ }^{58} \mathrm{On}$ the other hand, a more restrictive provision of Art. 87 GDPR is characterized as a specific opening clause since it regulates an implementation by Member States in a special area of national identification numbers or other identifiers of general application. ${ }^{59}$ Such a differentiation has also been recognized by the former European Commissioner for Justice, Consumers and Gender Equality, Ms. Jourová, in her answer to the parliamentary question from July 2018 on the opening clauses in the GDPR.${ }^{60}$ Here, she recognized that despite the direct applicability of the GDPR, "Member States must take necessary legislative steps, for instance, to set up national supervisory authorities, to choose an accreditation body or to lay down rules for the reconciliation of freedom of expression and data protection." She also accentuated the possibility for Member States "to put in place specific rules for certain specified processing situations (so-called 'specification clauses')", thereby referring to the above mentioned specific clauses. An example of it are opening clauses in the context of employment, where Art. 88 GDPR enables Member States to adopt more specific provisions in the employment context through legislation or collective agreements. ${ }^{61}$

55 Sharma, S., Data Privacy and GDPR Handbook, Wiley, USA, 2019, pp. 290 et seq. On the other hand, Voigt and von dem Bussche propose a classification of the opening clauses according to their subject and content, which partly corresponds to proposed systematization. Voigt; von dem Bussche, op. cit. note 50, pp. 290 et seq.

56 Kühling, et al., op. cit., note 46, p. 9; Bozkurt, op. cit., note 43, p. 34

57 Under Art. 23 GDPR, Member States can restrict the rights of data subjects under Art. 12-22 GDPR, if conditions and criteria of Art. 23 GDPR are met (especially to safeguard the public interest)

58 Art. 85 GDPR enables to Member States to reconcile requirements of the GDPR with the right to freedom of expression and information. See Voigt; von dem Bussche, op. cit., note 50, p. 294

59 According to Art. 87 GDPR, Member States can set specific conditions for the processing of national identification numbers or identifiers of general application

60 European Parliament, Parliamentary questions, Answer given by Ms. Jourová on behalf of the Commission, 13 July 2018, [https://www.europarl.europa.eu/doceo/document/P-8-2018-003121-ASW_ EN.html] Accessed on 15 March 2020

${ }_{61}$ Art. 88 GDPR refers to purposes of recruitment, performance of the employment contract, planning and organizing of work, equality and diversity, health and safety at work. National law provisions of Member States adopted under Art. 88(1) GDPR have to be notified to the Commission (Art. 88(3) GDPR) 
There are further attempts of systematization of opening clauses under the GDPR, which follow other division criteria and can result in an overlap with already presented categories. For example, Müller proposes a differentiation of opening clauses, depending on whether they provide specification, formation, exceptions, deviations, adjustments, reinforcements or comparable margins of discretion for Member States. ${ }^{62}$ In doing so, he creates a whole line of subcategories of clauses to which opening clauses can belong to, such as clauses on reinforcement, alteration, exception, and other sorts of clauses. For example, a reinforcement clause allows Member States to provide a more stringent regime of a certain regulatory area beyond the prescribed rules of the secondary harmonization measure. ${ }^{63}$ To such a clause belongs Art. 9(4) GDPR, whose content (facultatively) enables Member States to introduce additional conditions or restrictions in relation to processing of particularly sensitive data, such as genetic, biometric, or health data. ${ }^{64}$ On the other hand, Art. 6(2) GDPR would fall under the so-called formation clauses allowing Member States to specify their content at the national level. ${ }^{65}$ The content of this provision regulating the lawfulness of processing ${ }^{66}$ allows Member States the adoption or maintenance of more specific provisions on which data processing can be lawfully based. ${ }^{67}$ Another category of clauses are the so-called referring clauses, which create a link between harmonization measure rules and the national law of Member States by referring to the already existing legal solutions in Member States' national laws. ${ }^{68}$ As an example, we refer again to Art. 9 GDPR on the processing of particularly sensitive personal data, where references to Member State national laws can be found in almost all exceptions of Art. 9(2) GDPR. ${ }^{69}$ The

62 Müller, op. cit., note 44, p. 94. A similar differentiation of opening clauses according to their functions, depending on whether they allow Member States to specify, supplement or modify their content, is followed by Kühling; Martini, et al., op. cit., note 46, p. 9

63 Müller, op. cit., note 44, p. 98 (germ. Verstärkungsklausel)

64 Additional condition was introduced in German law requiring written consent under $\$ 8(1)$ of the Genetics Diagnostics Act (germ. Gendiagnostikgesetz) of 31 July 2009 (published in the Federal Law Gazette Part I, p. 2529, 3672), revised version published in the Federal Law Gazette Part I, p. 1626 on 20 November 2019. See Mester, B., DSGVO BDSG, in: Taeger J.; Gabel, D. (eds.), $3^{\text {rd }}$ ed., Deutscher Fachverlag, Frankfurt am Main, 2019, Art. 9, para. 37

65 Müller, op. cit., note 44, p. 99 (germ. Gestaltungsklausel)

66 See the first judgment of the CJEU interpreting Art. 6 GDPR in Case C-673/17 Planet49 [2019] OJ C 413. See also Opinion of the AG Szpunar of 21 March 2019, Case C-673/17, Planet 49 [2019]

${ }_{67}$ Art. 6(2) GDPR: "Member States may maintain or introduce more specific provisions to adapt the application of the rules of this Regulation with regard to ... by determining more precisely specific requirements for the processing and other measures to ensure lawful and fair processing including for other specific processing situations as provided for in Chapter IX". See Schwartmann et al., op. cit., note 48, Art. 6 GDPR para. 152

68 Müller, op. cit., note 44, p. 101 (germ. Verweisungsklauseln)

69 On more restrictive use of opening clauses see Dreyer S.; Schulz W., The General Data Protection Regulation and Automated Decision-making: Will it deliver?, Bertelsmann Stiftung, 2019, p. 40 
exception clauses encompass rules such as Art. $23 \mathrm{GDPR},{ }^{70}$ according to which Member States may impose legislative restrictions on the rights and obligations of data subjects due to various reasons, including the national or public security, defense, etc. ${ }^{71}$ Finally, Müller also recognizes the adjustment clauses, which give the Member States more or less discretion for the purpose of their implementation. ${ }^{72}$ The author recognize an example of an adjustment clause transplanted from DPD in Art. 84 GDPR, pursuant to which Member States should determine and adopt effective, proportionate, and dissuasive sanctions and measures against the violations of GDPR rules. However, since EU regulations are generally binding and directly applicable, Müller considers adjustment clauses to be in direct conflict with the legal nature of EU regulations. ${ }^{73}$ Nonetheless, authors of this paper consider that the provisions of EU secondary law act demanding effective enforcement of harmonization measures, of either a regulation or directive, should be categorized as enforcement clauses. Such clauses are typical in EU secondary law and they actually do not request the implementation of the harmonization measures but rather its effective enforcement at the level of Member States. ${ }^{74}$ This is in accordance with the definitions of EU directives and regulations as a means of harmonization (Art. 288 TFEU) and the principle of loyalty and sincere cooperation, as defined in Art 4(3) TEU. The latter demands from Member States to cooperate with each other and EU institutions in order to achieve Union goals and to "take any appropriate measure, general or particular, to ensure fulfilment of the obligations arising out of the Treaties or resulting from the acts of the institutions of the Union," including EU regulations and directives as harmonization measures.

\section{FINAL REMARKS}

Despite the brave attempts of legal scholars to categorize and find the meaning of particular opening clauses in the GDPR, this issue still presents an insufficiently explored matter. A confirmation of this conclusion comes directly from legal practice, as seen in the answer of Ms. Jourová to a parliamentary question concerning the interpretation and application of opening clauses under the GDPR. ${ }^{75}$ First insights can also be drawn from the national case law of Member States. In Septem-

\footnotetext{
70 Müller, op. cit., note 44, p. 104 (germ. Ausnabmeklauseln)

71 See Voigt; von dem Bussche, op. cit., note 50, p. 291

72 Müller, op. cit., note 44, p. 95 (germ. Anpassungsklauseln)

73 Ibid., p. 96.

74 See Mišćenić, E., The Effectiveness of Judicial Enforcement of the EU Consumer Protection Law, in: Meškić, Z. et al. (eds.), Balkan Yearbook of European and International Law, Springer International, Cham, 2020, p. 1 et seq.

75 European Parliament, note 60
} 
ber 2018, the German Federal Administrative Court (germ. Bundesverwaltungsgericht) adopted a ruling dealing with the margin of discretion of Member States when implementing opening clauses from Art. 6 GDPR into their national law. ${ }^{76}$

Another very important and insufficiently investigated issue is the relation of opening clauses to the harmonization of EU law. As seen within the lines of this paper, the authors examine whether GDRP as an EU regulation genuinely follows the aim of harmonization in EU law. Numerous options and possibilities leaving a wider or narrower margin of discretion to Member States significantly affects the legal nature and the manner of functioning of this particular EU regulation. On the one hand, numerous opening clauses are transforming the GDPR as a regulation into another harmonization measure, namely, an EU directive. On the other hand, opening clauses are supporting the creation of further differences between the laws of Member States, ${ }^{77}$ which is not the ultimate goal of an EU regulation or the harmonization of EU law. This can also be supported by first reports on the implementation of the GDPR in EU Member States, pointing to significant discrepancies between legal solutions, which has resulted from the use of the opening clauses. ${ }^{78}$

The creation of diverging legal solutions is at odds with EU principles of subsidiarity and proportionality, which should guarantee appropriate, necessary, and better legislative solutions at the EU level. It is also in direct conflict with the aim of harmonization, i.e., approximation of laws, or in other words, with the goal of removal of all barriers to the internal market. As rightly emphasized by Ms. Jourová in her answer to the parliamentary question, "Any measure which would have the result of creating an obstacle to the direct effect of the GDPR or of jeopardizing its simultaneous and uniform application in the EU would be contrary to the Treaties." ${ }^{79}$ Different legal solutions at the level of Member States undermine the

76 Judgment of Federal Administrative Court (germ. Bundesverwaltungsgericht) of 27 September 2018, Az. 7 C 5.17 concerning the right to information regarding an employment of relatives financed by public funds

77 See Chakarova, op. cit., note 49, pp. 43 et seq; Feiler, L., Öffnungsklauseln in der Datenschutz-Grundverordnung - Regelungsspielraum des österreichischen Gesetzgebers, jusIT 2016/93, Lexis Nexis Verlag Austria, Vienna, 2016, pp. 210 et seq.

78 Mc Cullagh K.; Tambou O.; Bourton S. (eds.), National Adaptations of the GDPR, Collection Open Access Book, Blogdroiteuropeen, Luxembourg, 2019, pp. 24 et seq. On the other hand, the European Commission Report appraises the EU's progress in implementing the GDPR by accentuating that "the data protection framework is in place in Member States". See Communication From the Commission to the European Parliament and the Council, Data protection rules as a trust-enabler in the EU and beyond - taking stock, COM(2019) 374 final, Brussels, 24 July 2019, p. 2

79 European Parliament, note 60 
legal certainty for those acting on the EU internal market. ${ }^{80}$ Bearing in mind the settled CJEU case law on the guarantee of 'full effect' of EU law, ${ }^{81}$ through effective and consistent implementation, interpretation and application of harmonized rules, the presented arguments thus lead to a conclusion that the opening clauses of the GDPR are more undermining than supporting the aim of harmonization of EU law. ${ }^{82}$

\section{REFERENCES}

\section{BOOKS AND ARTICLES}

1. Albrecht, J. P., How the GDPR Will Change the World, EDPL, no. 3, 2016, pp. 287-289

2. Annegret, E., The Choice of Legal Basis for Acts of the European Union: Competence Overlaps, Institutional Preferences, and Legal Basis Litigation, Springer International Publishing, Cham, 2018

3. Bozkurt, Ö., EU-DSGVO und Compliance. Rechtliche und wirtschaftliche Herausforderungen, Igel Verlag RWS, Hamburg, 2018

4. Chakarova, K. Y., General Data Protection Regulation: Challenges Posed by the Opening Clauses and Conflict of Laws Issues, Stanford-Vienna European Union Law Working Paper no. 41, 2019

5. Craig P.; De Burca G., EU Law: Text, Cases, and Materials, Oxford University Press, 6th ed., 2015

6. Dreyer S.; Schulz W., The General Data Protection Regulation and Automated Decision-making: Will it deliver?, Bertelsmann Stiftung, 2019

7. Feiler, L.; Forgó N., EU-DSGVO: EU-Datenschutz-Grundverordnung, Verlag Austria, Vienna, 2016

8. Feiler, L., Öffnungsklauseln in der Datenschutz-Grundverordnung - Regelungsspielraum des österreichischen Gesetzgebers, jusIT 2016/93, LexisNexis Verlag Austria, Vienna, 2016, pp. 210-212

9. Gebauer, M, Unification and Harmonization of Laws, in: Max Planck Encyclopedias of International Law [MPIL], 2009

10. Halson, R.; Campbell, D., Harmonisation and its discontents: A transaction costs critique of a European contract law, in: Devenney, J.; Kenny, M. (eds.), The Transformation of European

80 Mišćenić, op. cit. note 3, p. 148

81 ECJ, Case C-166/73 Rheinmühlen-Düsseldorfv Einfuhr-und Vorratsstelle für Getreide und Futtermittel [1974] ECR 33, para. 2

82 Similar doubts with respect to research exemptions under the GDPR are expressed by Mondschein, C. F.; Monda, C., The EU's General Data Protection Regulation (GDPR) in a Research Context, in: Kubben, P.; Dumontier, M.; Dekker, A., (eds.), Fundamentals of Clinical Data Science, Springer, 2019, p. 60. See also Nolan, K., GDPR: Harmonization or Fragmentation? Applicable Law Problems in EU Data Protection Law, Berkley Technology Law Journal, 2018. The opposite view was taken by Albrecht, J. P., How the GDPR Will Change the World, EDPL, no. 3, 2016, p. 287 
Private Law: Harmonisation, Consolidation, Codification or Chaos? Cambridge University Press, Cambridge, 2013, pp. 100-130

11. Hofmann, J.; Johannes, P., DS-GVO: Anleitung zur autonomen Auslegung des Personenbezugs, ZD, C.H.Beck, Munich, 2017, pp. 2017-226

12. Klamert, M., What We Talk About When We Talk About Harmonisation, Cambridge Yearbook of European Legal Studies, No. 17, 2015, pp. 360-379

13. Kühling, J. et. al., Die Datenschutz-Grundverordnung und das nationale Recht - Erste Überlegungen zum innerstaatlichen Regelungsbedarf, Monsenstein und Vannerdat, Münster, 2016

14. Kühling, J.; Martini, M., Die Datenschutz-Grundverordnung: Revolution oder Evolution im europäischen und deutschen Datenschutzrecht?, EuZW, C.H.Beck, Munich, 2016, pp. 448454

15. Laue, P., Öfnungsklauseln in der DS-GVO - Öffnung wohin? Geltungsbereich einzelstaatlicher (Sonder-)Regelungen, ZD, C.H. Beck, Munich, 2016, pp. 643-647

16. Lorenzmeier, S., Europarecht - schnell erfasst, $5^{\text {th }}$ ed., Springer, Berlin, Heidelberg, 2017

17. Lohse, E. J., The Meaning of Harmonisation in the Context of European Community Law - a Process in Need of Definition, in: Andenas, M. T.; Baasch Andersen, C., (eds.), Theory and Practice of Harmonisation, Edward Elgar, Cheltenham, 2012, pp. 282-313

18. Mak, V., Full Harmonization in European Private Law: A Two-Track Concept, European Review of Private Law, No. 20, 2012, pp. 213-235

19. Mc Cullagh K.; Tambou O.; Bourton S. (eds.), National Adaptations of the GDPR, Collection Open Access Book, Blogdroiteuropeen, Luxembourg, 2019

20. Mester, B., DSGVO BDSG, in: Taeger J.; Gabel, D. (eds.), $3^{\text {rd }}$ ed., Deutscher Fachverlag, Frankfurt am Main, 2019

21. Mišćenić, E., Uniform Interpretation of Article 4(2) of UCT Directive in the Context of Consumer Credit Agreements: Is it possible? Revue du droit de l'Union européenne, no. 3, pp. 127-159

22. Mišćenić, E., Legal Risks in Development of EU Consumer Protection Law, Legal Risks in EU Law, in: Mišćenić, E.; Raccah A. (eds.) Interdisciplinary Studies on Legal Risk Management and Better Regulation in Europe, Springer International, Cham, 2016, pp. 135-163

23. Mišćenić, E., Mortgage Credit Directive (MCD): Are Consumers Finally Getting the Protection They Deserve? in: Slakoper, Z. (ed.), Liber amicorum in honorem Vilim Gorenc, Faculty of Law, University of Rijeka, 2016, pp. 219-260

24. Mišćenić, E., The Effectiveness of Judicial Enforcement of the EU Consumer Protection Law, in: Meškić, Z., et al. (eds.), Balkan Yearbook of European and International Law, Springer International, Cham, 2020, pp. 1-25

25. Mondschein, C. F.; Monda, C., The EU's General Data Protection Regulation (GDPR) in a Research Context, in: Kubben, P.; Dumontier, M.; Dekker, A., (eds.), Fundamentals of Clinical Data Science, Springer, 2019, pp. 55-71

26. Müller-Graff, P.-C., EU Directives as a Means of Private Law Unification, Towards a European Civil Code, in: Hartkamp, A. et al. (eds.), $4^{\text {th }}$ ed., Wolters Kluwer, Alphen aan der Rijen, 2011, pp. 149-183 
27. Müller, M., Die Öffnungsklauseln der Datenschutzgrundverordnung - Ein Beitrag zur Europäischen Handlungsformenlehre, Wissenschaftliche Schriften der WWU, Münster, 2018

28. Nolan, K., GDPR: Harmonization or Fragmentation? Applicable Law Problems in EU Data Protection Law, Berkley Technology Law Journal, 2018, pp. 1-4

29. Obwexer, W., Harmonisierung und Optionalität - stehen Öfnungsklauseln der Verwirklichung des Binnenmarkts entgegen?, in: König, D.; Uwer, D. (eds.), Grenzen Europäischer Normgebung, $1^{\text {st }}$ ed., Bucerius Law School Press, Hamburg, 2015, pp. 54-76

30. Pötters, S., Datenschutz-Grundverordnung: DS-GVO, in: Gola, P (ed.), $2^{\text {nd }}$ ed., C.H.Beck, Munich, 2018

31. Roßnagel, A., Umsetzung der Unionsregelungen zum Datenschutz - Erste Erfahrungen mit der Datenschutz-Grundverordnung aus rechtswissenschaftlicher Sicht, DuD, Springer Gabler, Wiesbaden, 2018, pp. 741-745

32. Schwartmann, R.; Jaspers, A.; Thüsing, G., Kugelman, D. (eds.), DS-GVO/BDSG, Datenschutz-Grundverordnung Bundesdatenschutzgesetz, C.F. Müller, Heidelberg, 2018

33. Sharma, S., Data Privacy and GDPR Handbook, Wiley, USA, 2019

34. Ehmann, E.; Selmayr, M. (eds.), Datenschutz-Grundverordnung: DS-GVO, $2^{\text {nd }}$ ed., C.H. Beck, Munich, 2018

35. Schröder, M., EUVIAEUV, in: Streinz (eds.), $3^{\text {rd }}$ ed., C.H. Beck, Munich, 2018

36. Voigt, P.; von dem Bussche, A., EU-Datenschutz-Grundverordnung (DSGVO), Springer, Berlin, Heidelberg, 2018

37. Voigt, P., von dem Bussche, A., The EU General Data Protection Regulation (GDPR): A Practical Guide, Springer, Cham, 2017

38. Weatheril, S., Law and Values in the European Union, Oxford University Press, 2016

39. Weatheril, S., Maximum versus Minimum Harmonization: Choosing between Unity and Diversity in the Search for the Soul of the Internal Market, in: Shuibhne N. N.; Gormley L. W. (eds.), From Single Market to Economic Union: Essays in Memory of John A. Usher, Oxford University Press, Oxford, 2012, pp. 175-199

\section{COURT OF JUSTICE OF THE EUROPEAN UNION}

1. Case C-376/98 Germany v Parliament and Council [2000] ECR I-08419

2. Case 101/76 Koninklijke Scholten Honig v Council and Commission [1977] ECR 797

3. Case C-34/73 Fratelli Variola SpA. v Amministrazione delle finanze dello Stato [1973] ECR 981

4. Case C-43/71 Politi v Ministero delle finanze [1971] ECR 1039

5. Case C-478/99 Commission v Sweden [2002] ECR I-04147

6. Case C-11/92 The Queen $v$ Secretary of State for Health, ex parte Gallaher and Others [1993] ECR I-03545

7. Case C-819/79 Germany v Commission [1981] ECR 21

8. Case C-166/73 Rheinmühlen-Düsseldorf v Einfuhr- und Vorratsstelle für Getreide und Futtermittel [1974] ECR 33 
9. Case C673/17, Planet49 [2019] OJ C 413

10. Opinion of AG Stix-Hackl of 12 July 2005, Case C-436/03, Parliament v Council [2006] ECR I-03733

11. Opinion of the AG Szpunar of 21 March 2019, Case C-673/17, Planet 49 [2019]

\section{EU LAW}

1. Consolidated versions of the Treaty on European Union and the Treaty on the Functioning of the European Union [2016] OJ C 202/13

2. Regulation (EU) $2016 / 679$ on the protection of natural persons with regard to the processing of personal data and on the free movement of such data, and repealing Directive 95/46/ EC (General Data Protection Regulation) [2016] OJ L 119/1

3. Regulation (EU) No 524/2013 on online dispute resolution for consumer disputes and amending Regulation (EC) No 2006/2004 and Directive 2009/22/EC (Regulation on consumer ODR) [2013] OJ L 165/1

4. Commission Implementing Regulation (EU) 2015/1051 on the modalities for the exercise of the functions of the online dispute resolution platform, on the modalities of the electronic complaint form and on the modalities of the cooperation between contact points provided for in Regulation (EU) No 524/2013 of the European Parliament and of the Council on online dispute resolution for consumer disputes [2015] OJ L 171/1

5. Directive 2011/83/EU on consumer rights, amending Council Directive 93/13/EEC and Directive 1999/44/EC of the European Parliament and of the Council and repealing Council Directive 85/577/EEC and Directive 97/7/EC of the European Parliament and of the Council [2011] OJ L 304/64

6. Directive 2014/17/EU on credit agreements for consumers relating to residential immovable property and amending Directives 2008/48/EC and 2013/36/EU and Regulation (EU) No 1093/2010 [2014] OJ L 60/34

7. Directive 95/46/EC of the European Parliament and of the Council of 24 October 1995 on the protection of individuals with regard to the processing of personal data and on the free movement of such data [1995] OJ L 281/31 (DPD)

8. Proposal for a Regulation of the European Parliament and of the Council on a Common European Sales Law, COM/2011/0635 final - 2011/0284 (COD)

9. European Commission, Communication From the Commission to the European Parliament and the Council, Data protection rules as a trust-enabler in the EU and beyond-taking stock, COM(2019) 374 final, Brussels, 24 July 2019

\section{LIST OF NATIONAL REGULATIONS, ACTS AND COURT DECISIONS}

1. Draft Law of the Federal Government (Bundesregierung) to adapt the German Data Protection Law to GDPR (germ. Entwurf eines Gesetzes zur Anpassung des Datenschutzrechts an die Verordnung (EU) 2016/679 und zur Umsetzung der Richtlinie (EU) 2016/680, DatenschutzAnpassungs-und-Umsetzungsgesetz EU - DSAnpUG-EU), BT-Drs. 18/11325, 24.2.2017 
2. Genetics Diagnostics Act (germ. Gendiagnostikgesetz) of 31 July 2009 (published in the Federal Law Gazette Part I, p. 2529, 3672), revised version published in the Federal Law Gazette Part I, p. 1626 on 20 November 2019)

3. Federal Administrative Court (germ. Bundesverwaltungsgericht), Judgment of 27 September 2018, Az. 7 C 5.17

\section{WEBSITE REFERENCES}

1. European Parliament, Parliamentary questions, Answer given by Ms. Jourová on behalf of the Commission, 13 July 2018, [https:/www.europarl.europa.eu/doceo/document/P-82018-003121-ASW_EN.html] Accessed on 15 March 2020 